\title{
Impact of Urban Land Transformation on Water Bodies in Srinagar City, India
}

\author{
Shahab Fazal, Arshad Amin \\ Department of Geography, Aligarh Muslim University, Aligarh, India. \\ Email: shahabfazal@rediffmail.com \\ Received November $8^{\text {th }}$, 2010; revised December $24^{\text {th }}$, 2010; accepted February $19^{\text {th }}, 2011$.
}

\begin{abstract}
Human actions rather than natural forces are the source of most contemporary changes in the state and flows of the biosphere. Understanding these actions and the social forces that drive them is crucial to understanding, modelling and predicting local, regional as well as global environmental change and also for managing and responding to such change. The present study investigates the patterns of urban land transformation in Srinagar City, which lies in fragile hill eco-system of Kashmir valley. The results points towards unplanned and haphazard urban expansion and transformation. These transformations have severely destroyed the water bodies both in terms of area as well as its quality.
\end{abstract}

Keywords: Urban, Land Transformation, Water Bodies, Agriculture, Marshy

\section{Introduction}

Land transformation is one of the most important fields of human induced environmental transformation, with an extensive history dating back to antiquity [1]. Land transformation accelerated and diversified with the onset of the Industrial Revolution, the globalization of the world economy and the expansion of population and technological capacity. Land transformations, although localized, contribute to wider reaching, regional systemic processes. The demand for the products of the land is likely to continue growing in the foreseeable future. Maintaining the capacity of the land to sustain that demand will remain of fundamental importance. The level of concern elicited by current trends reflects the possibility that much land transformation in some sense constitutes land degradation [2]. As land cover, settlement represents the most profound alteration of the natural environment by people, through the imposition of structures, buildings, paved surfaces, and compacted bare soils on the ground surface. Settlements also create demands that lead to other land-cover changes, such as the removal of vegetation and soil to extract sand, gravel, brick clays, and rock; the replacement of vegetation by planted cover in gardens, parks, sports grounds; the alienation of ground for landfill and waste treatment; wetlands and open space conversion for settlements and the use of land for transportation routes.

Alteration is nearly inseparable from human occupa- tion and use, and the goal is to encourage improvement and to counter forces that encourage degradation [3]. To assess what effect a particular land transformation and its consequences will have involves difficult issues of forecasting (future resource demands and opportunities as affected by technical and socioeconomic change) and evaluation (distribution and the rights of future generations). However, we now possess a better scientific knowledge of the physical extent, character and consequences of land transformation, which serves as the foundation for any such assessment.

The simultaneous rapid growth in both population and economic output per capita, and the consequent changes in land use pattern come at a cost to the natural environment [4-6]. Demographic growth stimulates structural change through multiplier effects and behavioural changes attract immigrants. Urban areas have become the centre of all the activities - they are expanding in size, land use is changing quickly, constantly intensifying urban lands and large-scale land transformation is taking place due to substantial increases in urban land value and thus these areas have acquired centre stage. Cities are man - made physical structure, placed in natural settings. If the cities are well placed, well planned, well built, they remain in aesthetic harmony with nature. But cities with rapid growth (mostly in developing countries) grow without planning and relationship between urban form (the built environment) and nature generates an unending source of tensions and controversies. Cities need more 
resources and thus constantly keep on expanding, from the urban core into suburbs in exurbs, separating people more and more distantly from natural landscape.

The present study focuses on to study the general pattern of urban expansion and land transformation in Srinagar city, further it also try to investigate specifically the impact of these land transformation on city's water bodies, considered as lifeline of the city. The rivers and lakes are notable not only for their size and volume, but also for providing habitats for aquatic fauna and flora, especially for a number of endemic species. Unfortunately, these bodies of water have been greatly affected by human-induced land use changes. The degradation of these bodies are largely attributed to extensive agricultural reclamation, resulting in negative ecological consequences, such as frequent flooding, a decline in biodiversity and the extinction of a number of endemic species [7]. In addition, water quality in most wetlands has also been heavily degraded, mainly due to wastewater discharges, all of which cause widespread eutrophication [8-10]. The Indian cities are found to be discharging up to $95 \%$ of wastewater directly into rivers, lakes and streams without any treatment at all. Consequently, the bacterial level resulting from human waste found in these water bodies are threefold higher than the world average and 50-fold higher than World Health Organization guidelines [11]. Moreover, land use activities such as deforestation and wetland reclamation also affect the quality and condition of freshwater bodies [12,13]. These land use activities are widespread across the Asian continent and are particularly pervasive in India.

\subsection{Study Area}

The present study is for Srinagar city, once called as "Paradise on Earth", but now the greed of man has transformed it in to a conflict zone. The study area lies between $33^{\circ} 59^{\prime} 14 " \mathrm{~N}$ and $34^{\circ} 12^{\prime} 37^{\prime \prime} \mathrm{N}$ latitude and $74^{\circ} 41^{\prime} 06^{\prime \prime} \mathrm{E}$ and $74^{\circ} 57^{\prime} 27^{\prime \prime} \mathrm{E}$ longitude, is summer capital of the state of Jammu and Kashmir. The city is located on both sides of the River Jhelum, locally called Vyeth in Kashmir (Figure 1). The study area spreads between the plains of vale of Kashmir along the river Jhelum. The general relief of the study area is $1580 \mathrm{~m}$ above mean sea level. The general terrain of the study area is moderate and represents hill topography. The population of Srinagar city in 1951 was 255679 which increased up to 952324 in 2001, recording a growth of +51.06 percent (the projected population for 2011 is about 1.5 million). The entire hill area is for the last many years are in turmoil with political, economic and social conflicts. At the same time, the city has also witnessed urban forces acting to transform the city landscape.

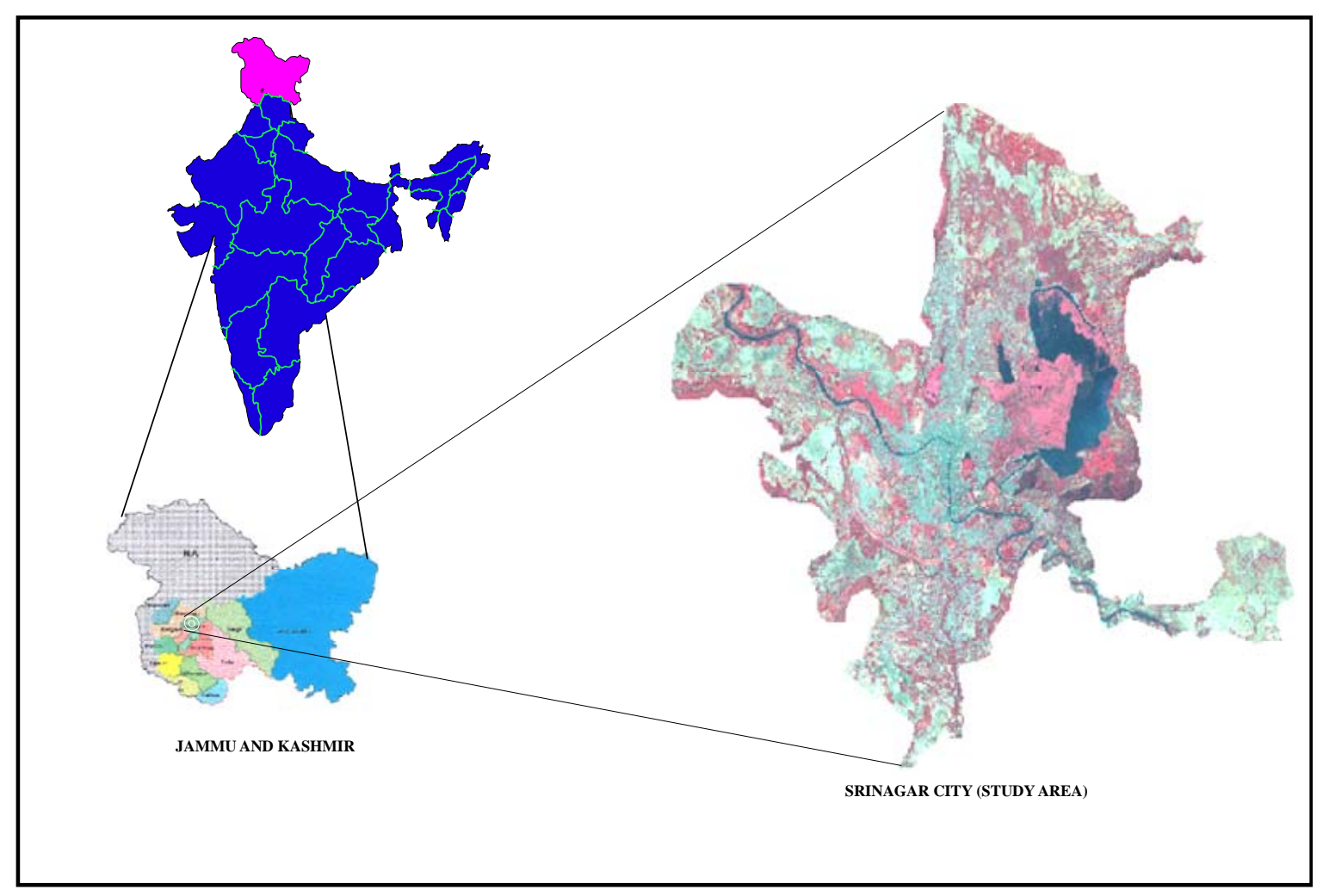

Figure 1. Location map of srinagar city. 


\section{Methods}

The study is mainly based on secondary sources of data, the data used for the preparation of Land use land cover of the study area is Town planning map of Srinagar city 1971 on 1:15000 scale. Similarly, the land use land cover for the later date was carried out using IRS-1D LISS III + PAN 2008 merged satellite imagery. Both the images were first geo-corrected and geo-referenced in Earth Resource Data Analysis System (ERDAS) Imagine 9.0 software, assigning Universal Transverse Mercator with World Geocoded system (UTM WGS 84) projection parameters. Further for assistance in the process of interpretation SOI toposheet was also geo-referenced and was given similar projection and datum. The area of interest (Municipal limits of Srinagar city) was extracted by sub-setting of the town planning map. Satellite imagery was stacked into different bands to produce a false color composite, the area of interest was extracted by sub-setting of the image. These images were digitized in GIS environment using ArcView 3.2a software in the form of polygons representing different land use land cover categories. The data was classified into 14 land use land cover classes spread over a total area of 23446.5 hectares of the Srinagar city (which incidentally is also the Municipal limits). The trend and pattern of urban expansion was calculated and every polygon representing the particular class was quantified and displayed in respective maps.

\section{Results and Discussion}

The present study for Srinagar city is focused to analyze spatial and temporal information of land cover and land use patterns as well as the transformations therein. Remote sensing, although challenged by the spatial and spectral heterogeneity of urban environments $[14,15]$ was used for the study as these sources are found to be an appropriate source of urban data to investigate such studies [16,17].

The present study is spread over 23446.5 hectares of land, which is also the municipal limit of the Srinagar city. From the perusal of Table 1 and Figures 2 and 3, it is evident that Srinagar city has witnessed large-scale changes in land use in and around the city. The statistics shows that urban area has increased from 2410 hectare in 1971 (Box 1) to 6224 hectare in 2008 (an increase of 158 percent). Similarly built up area has increased from 2556.5 hectare to 6623.5 hectare (159 percent). All these increases are at the expense of non - built up area, which shrunk from 20890 hectare to 16823 hectare (a decrease of 19 percent) during the study period. Significantly, the city has witnessed major land use changes among classes such as residential area, commercial area, parks and gardens and industrial area. These changes were basically swallowed the agricultural and forest land as well as water bodies of the study area. Significantly, the water bodies and marshy lands loses 1449 hectares to the urban expansion of Srinagar city.

The salient feature of this land transformation is that Srinagar city has recorded a significant increase in built up area and this is mainly because of population growth and development in secondary and tertiary occupation structure. But this built up expansion was haphazard and without much planning. The down town area of the city is characterized by narrow lanes, open drains, poor solid waste collection and dumping facilities, lack of open spaces, poor infrastructural facilities etc. Expansion has taken place largely in a radial manner along the roads. However because of the topographical limitations the expansion is restricted in the hilly areas of Alestang in the north, the mountain peaks of Zabarwan and Basiwan in the east and the hilly tracks of Khrew and Khanmou in the south east, also the marshy area of the once Anchar Lake in the north west of the city, the general trend of expansion remained confined to the north south and west direction because of the leveled plain.

\subsection{Land Transformation in Srinagar City}

Land transformation is the process of identifying differences in the state of any phenomenon by observing it at different time periods. Land is in a continuous state of transformation as a result of various natural and manmade processes. During the study period, Srinagar city has not only expanded from its original size but there was significant interchange of land among various land use/cover classes. During the study period Srinagar city has under gone substantial land transformation, but only in some specific areas, which is the out come of social, economic, religious and cultural factors.

Table 2, and Figure 4, which are prepared applying G.I.S. technique, shows the changes in various urban land use class of the city. These changes are because of the development of city resulting in increased demand of land for residential, commercial, industrial etc. purposes. This demand of land along with site attraction, functional convenience, functional magnetism and the land value of that particular area ultimately influence the pace and direction of urban land transformation. The important land transformation was witnessed among residential, vacant, plantation/orchards, agriculture and water bodies/marshy lands. The residential area has increased by 2776 hectare, capturing land mainly from agriculture, vacant land, plantation and villages. Residential area also lost area for commercial development. Plantation/orchards land has reduced by 1395 hectare this loss was gain for residential, parks and orchards, restricted and vacant and other area. Vacant land has lost 262 hectares of land; it loses to residential class and exchanged land from agriculture and 
Table 1. Land use land cover of Srinagar city (1971 and 2008).

\begin{tabular}{lcccc}
\hline \multicolumn{1}{c}{ Land use } & $\mathbf{1 9 7 1}$ & $\mathbf{2 0 0 8}$ & Change & \% age Change \\
\hline 1. Residential & $1074.5(4.58 \%)$ & $3851(16.42 \%)$ & 2776.5 & 258.3 \\
2. Semi-urban Village & $146(0.62 \%)$ & $399(1.7 \%)$ & 253 & 173.2 \\
3. Commercial & $143.5(0.61 \%)$ & $268.5(1.14 \%)$ & 125 & 87.1 \\
4. Industrial & $90.5(0.39 \%)$ & $226.5(0.97 \%)$ & 136 & 150.2 \\
5. Parks/Gardens \& P.G & $140(0.59 \%)$ & $372(1.59 \%)$ & 232 & 165.7 \\
6. Restricted Area & $446(1.9 \%)$ & $715(3.04 \%)$ & 269 & 60.3 \\
7. Vacant & $517(2.2 \%)$ & $255(1.08 \%)$ & -262 & -50.6 \\
8. Agriculture & $14408(61.45 \%)$ & $10949(46.7 \%)$ & -3459 & -24 \\
9. Plantation/Orchard & $1266.5(5.40 \%)$ & $2622(11.18 \%)$ & 1395.5 & 110.1 \\
10. Forest & $346.5(1.47 \%)$ & $153.5(0.65 \%)$ & -193 & -55 \\
11. Barren & $539.5(2.3 \%)$ & $480(2.05 \%)$ & -59.5 & -11 \\
12. Marshy & $\mathbf{1 6 6 7 ( 7 . 1 \% )}$ & $\mathbf{4 6 8 . 5 ( 2 \% )}$ & $\mathbf{- 1 1 9 8 . 5}$ & $-\mathbf{7 1 . 8}$ \\
13. Water body & $\mathbf{2 1 4 5 . 5 ( 9 . 1 5 \% )}$ & $\mathbf{1 8 9 5 ( \mathbf { 8 . 0 8 } \% )}$ & $-\mathbf{2 5 0 . 5}$ & $\mathbf{- 1 1 . 6}$ \\
14. Others (Edu,Govt,Hosp,Relig) & $516(2.2 \%)$ & $791.5(3.37 \%)$ & 275 & 53 \\
\multicolumn{1}{c}{ TOTAL } & $\mathbf{2 3 4 4 6 . 5}$ & $\mathbf{2 3 4 4 6 . 5}$ & --- & --- \\
Total Built Up & 2556.5 & 6623.5 & 4067 & 159 \\
Total Non Built Up & 20890 & 16823 & -4067 & -19.46 \\
Total Urban Area & 2410.5 & 6224.5 & 3814 & 158.2 \\
\hline
\end{tabular}

Note: Area in hectares. SOURCE: Based on Town planning map of Srinagar city 1971 on 1:15000 scale and IRS-1D LISS; III + PAN 2008 merged satellite imagery of Srinagar city.

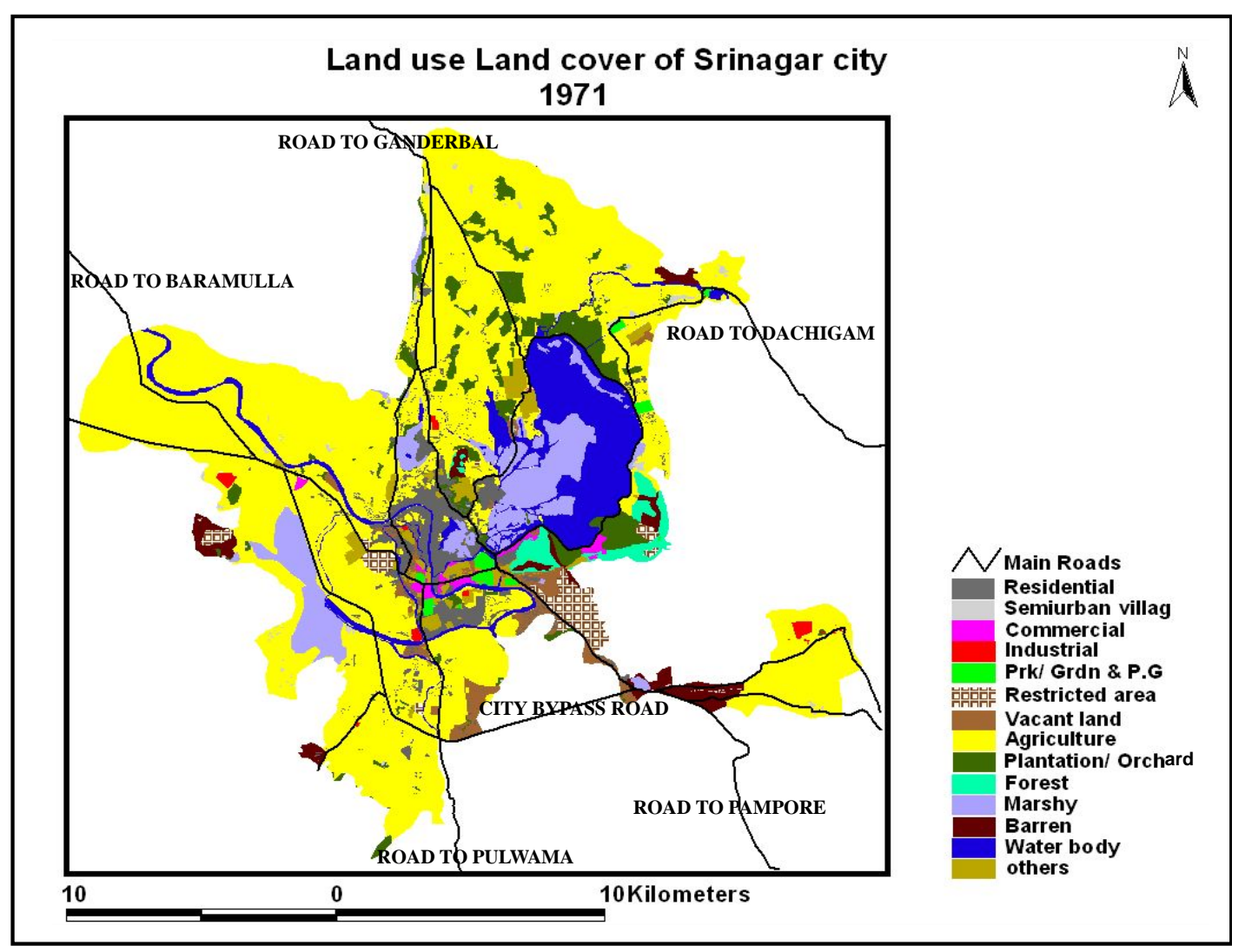

Figure 2. Land use land cover of srinagar city 1971. 


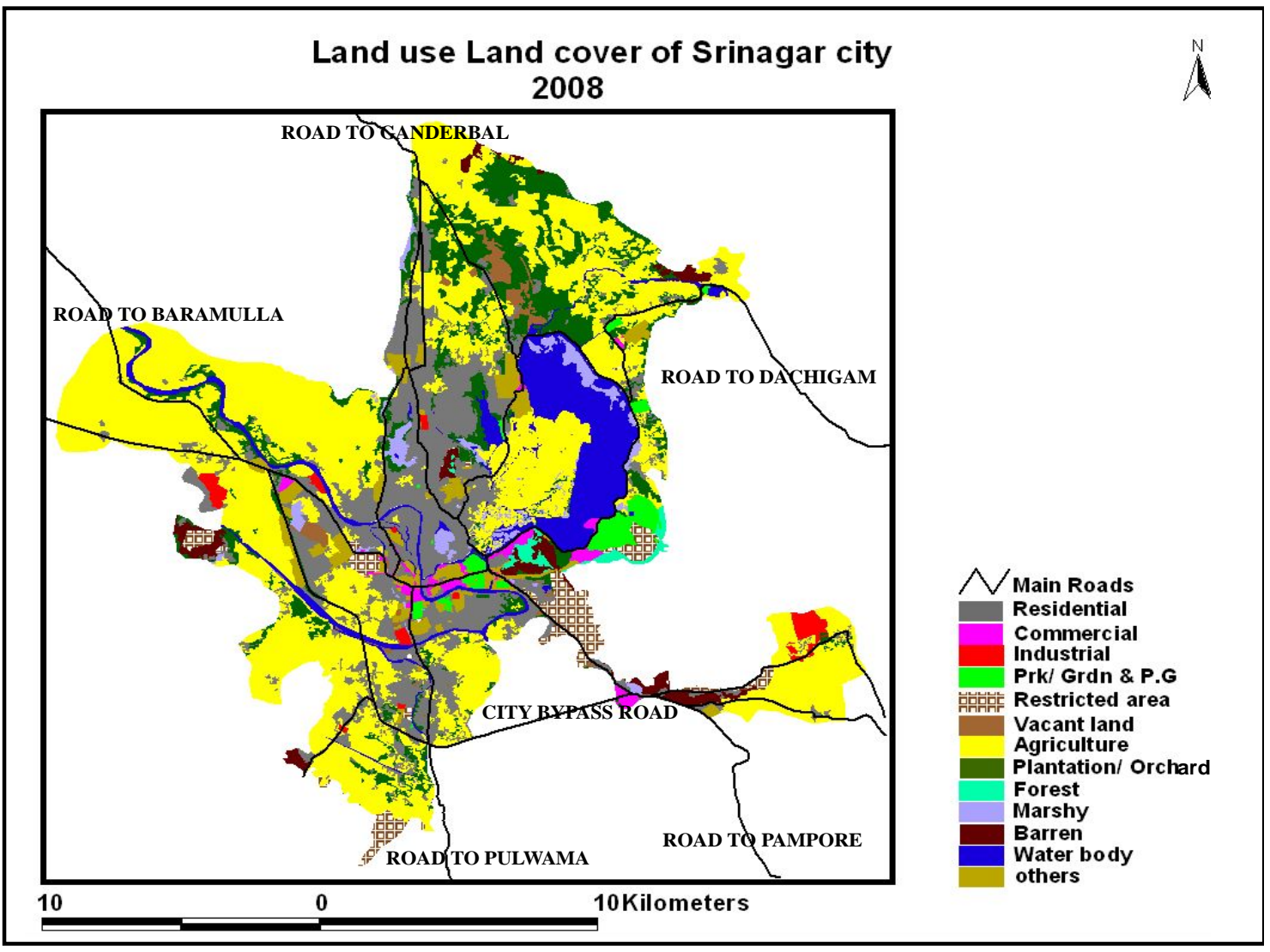

Figure 3. Land use land cover of srinagar city 2008.

Table 2. Srinagar city, land transformation (1971 - 2008).

\begin{tabular}{|c|c|c|c|c|c|c|c|c|c|c|c|c|c|c|c|}
\hline Land Use & $\begin{array}{c}1 \\
\text { Res }\end{array}$ & $\begin{array}{c}2 \\
\text { Vil }\end{array}$ & $\begin{array}{c}3 \\
\text { Com }\end{array}$ & $\begin{array}{c}4 \\
\text { Ind }\end{array}$ & $\begin{array}{c}5 \\
\text { Prk/gr }\end{array}$ & $\begin{array}{c}6 \\
\text { Rest }\end{array}$ & $\begin{array}{c}7 \\
\text { Vac }\end{array}$ & $\begin{array}{c}8 \\
\text { Agr }\end{array}$ & $\begin{array}{c}9 \\
\text { Pl/Orc }\end{array}$ & $\begin{array}{c}10 \\
\text { For }\end{array}$ & $\begin{array}{c}11 \\
\text { Mar }\end{array}$ & $\begin{array}{c}12 \\
\text { Bar }\end{array}$ & $\begin{array}{c}13 \\
\text { Was }\end{array}$ & $\begin{array}{c}14 \\
\text { Oth }\end{array}$ & $\begin{array}{c}\text { TOTAL } \\
\text { Area (2008) }\end{array}$ \\
\hline 1. Residential & 1074.5 & 146 & & & & & 210 & 2145 & 152.5 & & 77 & 60 & & & 3851 \\
\hline 2. Semi-urban Village & & 146 & & & & & 5.5 & 322.5 & & 71 & & & & & 399 \\
\hline 3. Commercial & 14 & & 143.5 & & & & 111 & & & & & & & & 268.5 \\
\hline 4. Industrial & & & & 90.5 & & & & 136 & & & & & & & 226.5 \\
\hline 5. Parks/Gardens \& P.g & & & & & 140 & & & & 150 & 40 & & 42 & & & 372 \\
\hline 6. Restricted & & & & & & 446 & 33.5 & 175.5 & 60 & & & & & & 715 \\
\hline 7. Vacant & & & & & & & 517 & 185 & 68.5 & & & & & & 255 \\
\hline 8. Agriculture & & & & & & & 109 & 14408 & 214 & & 1081.5 & & 148 & & 10949 \\
\hline 9. Plantation/Orchard & & & & & & & 21.5 & 1787 & 1266.5 & 39 & 108 & 47 & 43 & & 2622.5 \\
\hline 10. Forest & & & & & & & & & & 346.5 & & & & & 153.5 \\
\hline 11. Marshy & & & & & & & & 60 & & & 1667 & & 92 & & 468.5 \\
\hline 12. Barren & & & & & & & & 74 & & 43 & & 539.5 & & & 480 \\
\hline 13. Water body & & & & & & & & & & & 35 & & 2145.5 & & 1894.5 \\
\hline $\begin{array}{l}\text { 14. Others } \\
\text { (Edu,Govt, Hosp,Relig,.) }\end{array}$ & & & & & & & 25 & 126.5 & 44.5 & & 49 & 27.5 & 3 & 516 & 791.5 \\
\hline
\end{tabular}

Notes: Area in hectares. Figures in bold (diagonally) are area under that particular land use in 1971, while the figures in the same column represent the conversion in area to other land uses. Similarly, figures in the same row are increases in area, captured from other land uses. SOURCE: Based on IRS-1D LISS+PAN Satellite imagery (2008) and Town planning map (1971) of Srinagar city. 


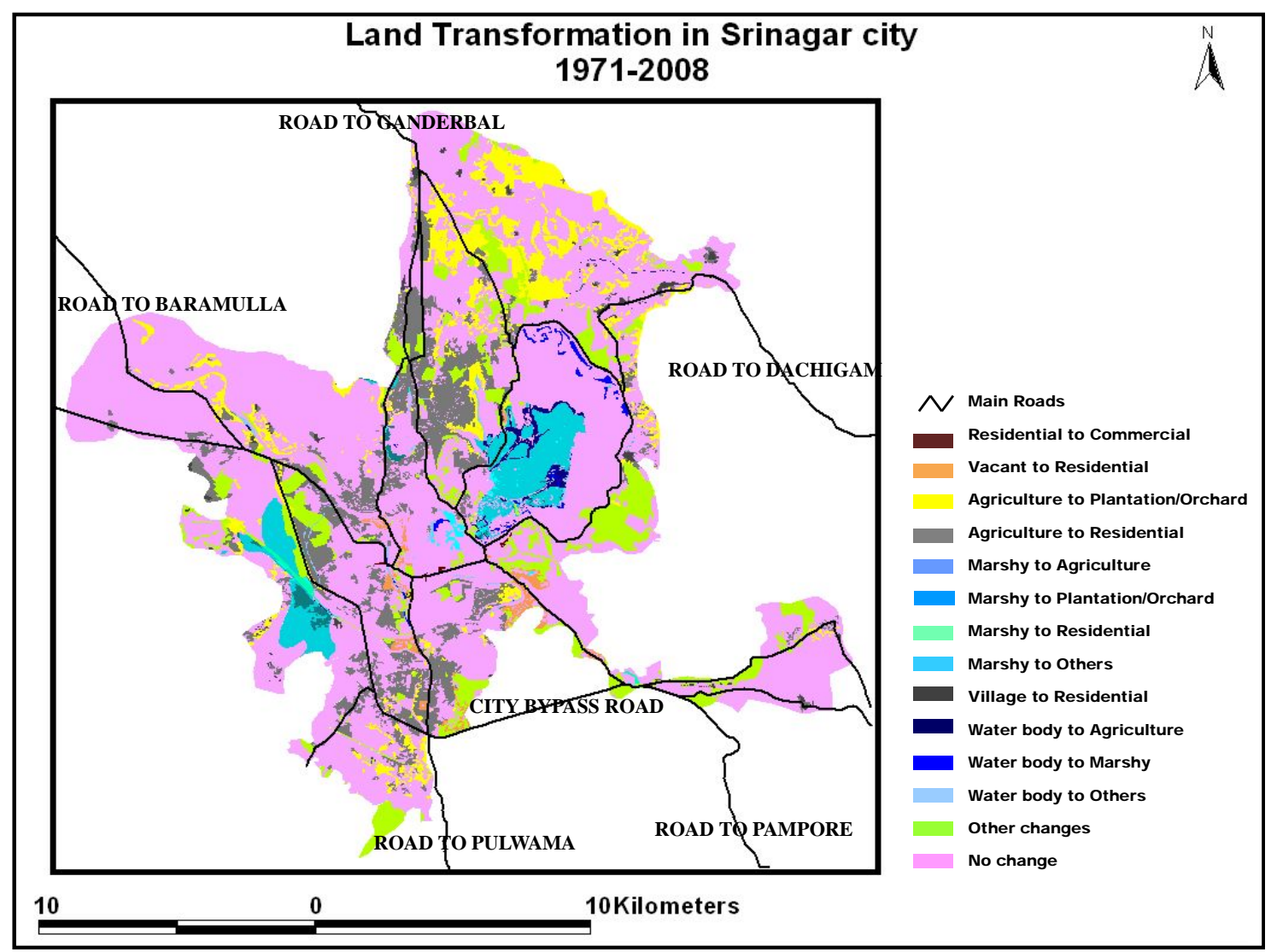

Figure 4. Land transformation in Srinagar city 1971-2008.

plantation/orchards. Another noticeable land transformation was in water bodies and marshy land, these two land use classes collectively lost 1449 hectares of land mainly to agriculture, residential and plantation/orchards.

Box 1. Transformation of water bodies and marshy areas in srinagar city $1971-2008$.

\begin{tabular}{|c|c|c|c|c|}
\hline S.no & Land cover & Area in 1971 (hectares) & Transformation & Area in 2008 (hectares) \\
\hline 1. & $\begin{array}{l}\text { Dal } \\
\text { Lake }\end{array}$ & $\begin{array}{l}\text { Water body (1538) } \\
\text { Marshy area (1009.5) }\end{array}$ & $\begin{array}{c}\text { Water body to Agriculture (148) } \\
\text { Water body to Marsh - (85) } \\
\text { Marshy to Agriculture - (650) } \\
\text { Marshy to plantation/Orchard (24.5) } \\
\text { Marshy to others - (20) } \\
\text { Marshy to Residential-(35) }\end{array}$ & $\begin{array}{l}\text { Water body (1305) } \\
\text { Marsh (315) }\end{array}$ \\
\hline 2. & $\begin{array}{l}\text { Nigeen } \\
\text { Lake }\end{array}$ & Water body - (110) & Water body to Plantation - (7) & Water body (103) \\
\hline 3. & $\begin{array}{c}\text { Brari } \\
\text { Nambal }\end{array}$ & $\begin{array}{l}\text { Water body - (28) } \\
\text { Marshy area - (72) }\end{array}$ & $\begin{array}{l}\text { Water body to Marsh - (7) } \\
\text { Marsh to Plantation/ Orchard - (16) }\end{array}$ & $\begin{array}{l}\text { Water body (21) } \\
\text { Marsh (56) }\end{array}$ \\
\hline 4. & Khushalsar & $\begin{array}{l}\text { Water body - (15) } \\
\text { Marshy area - (91) }\end{array}$ & $\begin{array}{l}\text { Marshy to Plantation/ Or- } \\
\text { chard-(33.5) }\end{array}$ & $\begin{array}{l}\text { Water body (15) } \\
\text { Marsh (57.5) }\end{array}$ \\
\hline 5. & $\begin{array}{c}\text { Rakh-i- } \\
\text { Gandakshah }\end{array}$ & Marshy-(494.5) & $\begin{array}{l}\text { Marshy to Agriculture - (431.5) } \\
\text { Marshy to Plantation/Orchard - (34) } \\
\text { Marshy to others - (29) }\end{array}$ & Completely Transformed \\
\hline
\end{tabular}




\subsection{Water Bodies of Srinagar City}

The Srinagar city has some very famous water bodies, which are not only tourist attractions but in many ways act as lifeline to the city. The water bodies include river Jhelum, Dal lake, Nigeen lake, Brari Nambal, and Khushalsar (Figure 5).

River Jhelum: River Jhelum rises from a beautiful spring called Verinag south east of Srinagar city. It drains the whole of the study area while flowing diagonally in south east to North West direction. It is spread over 454 hectares of the study area. Jhelum had numerous tributaries which included Kuth-i-kol, Tsont-i-kol, Mar or snake canal etc. the river Jhelum is also under urban anthropogenic pressure and there are evidences of deterioration in water quality.

Dal Lake: This lake is located on the east and north eastern part of the city, on the right bank of Jhelum, the lake is fed by the "Arrah" river, flows in a northerly extremity through a dark and deep channel called Tel Bal or river of oil. Dal Lake is the largest water body of Srinagar city and has been divided into three parts 1) Gagribal, 2) Lokut-Dal, and 3) Bud-Dal. Presently the lake is spread over 1620 hectares, consisting 1305 hectares of water body and 315 hectares of marshy area.

Nigeen Lake: Nigeen Lake is located to the west of Dal Lake about $9 \mathrm{kms}$ in the north of the city center and is connected to the lake by a narrow water channel at Ashai bagh. The area under this lake is 103 hectares. This is the only lake which did not have marshy banks.

Brari Nambal: Brari Nambal is located about $2 \mathrm{kms}$ in the north of Lal Chowk (CBD). Its northern part constitutes of water while its southern part is inundated with the marshy lands. The lake is spread over 77 hectares, consisting of 21 hectares water body and 56 hectares of marshy area.

Khushalsar: It is located about 6-7 kms away from the city center in the north. Khushalsar is a fresh water lake spread over 67 hectares.

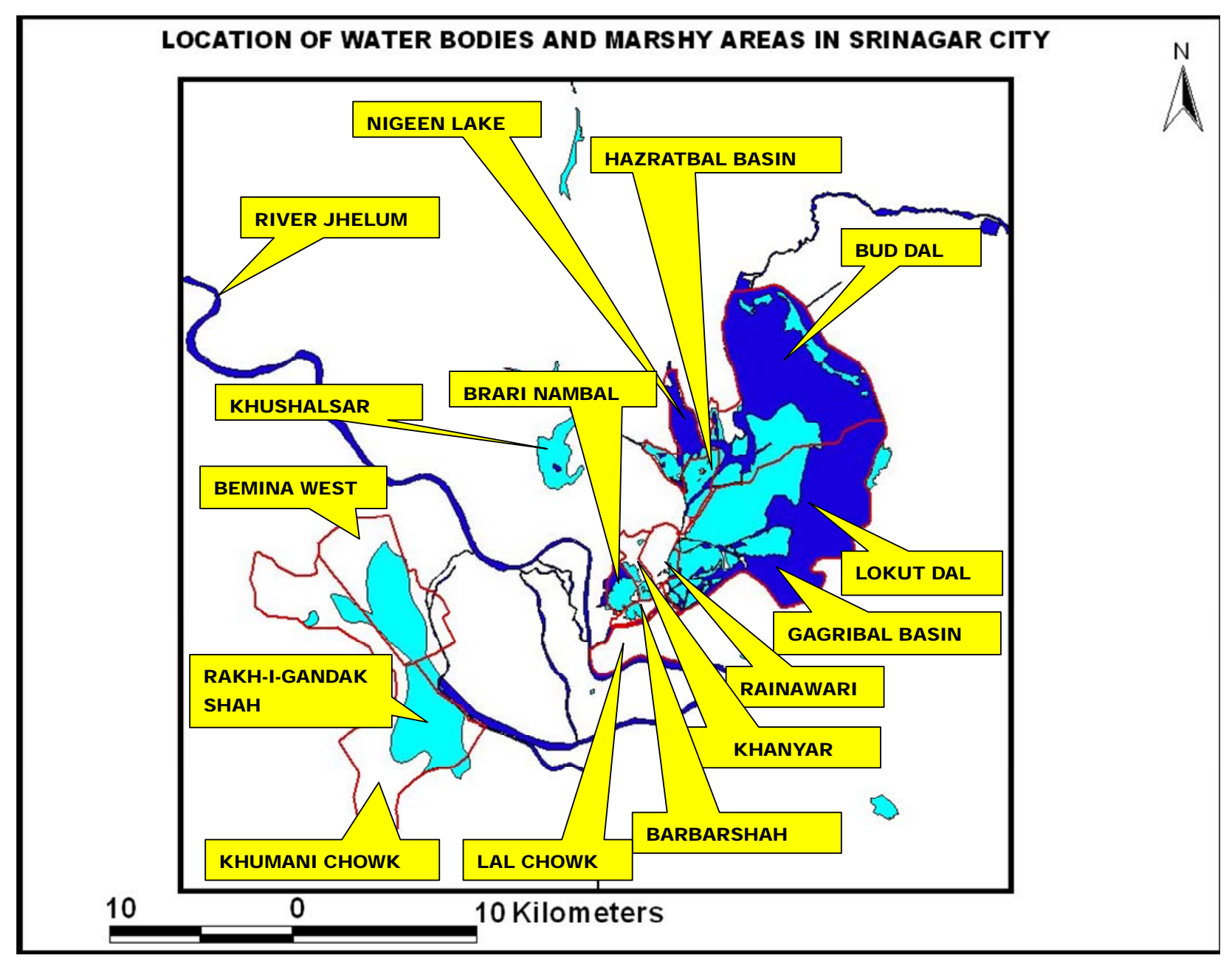

Figure 5. Location of water badies and marshy areas in srinagay city. 
Rakh-i-Gandakshah: Rakh-i-Gandakshah is located about $7 \mathrm{kms}$ from the city center in the western part of the study area where presently Bemina and Khumani Chowk exists. The area under this marsh was 494.5 hectares in the year 1971 and up to the year 2008 (Box 2) it got completely transformed to other land uses.

\subsection{Transformation of Water Bodies in Srinagar City}

The main focus of the present study is to investigate the impact of land transformation on water bodies, which is ecological critical land cover class of Srinagar city. The water bodies of the city are characterized by shallow banks, termed as marshy land, locally known as (dal-dal). Srinagar city currently has a total of 1895 hectares of land under water bodies and another 468 hectares of marshy lands (the shallow banks). Both of these land cover class have recorded decreases in their coverage area during the study period (Figure 6).

Water bodies have suffered degradation in both the area as well as in the quality of water, whereas marshy areas have been converted either into built-up land or floating vegetable gardens/floating gardens (locally known as Rad). The total area under water bodies was 2 145.5 hectares in 1971, which decreased to 1895 hectares in the year 2008 i.e., decreased by 250.5 hectares, losing its area to agriculture (148 hectares), marshy (92 hectares) and others ( 3 hectares). whereas, water bodies gained area from marsh (35 hectares). Similarly, Marshy area has decreased from 1667 hectares to 468.5 hectares during the study period, recording a decrease of 1198.5 hectares, it lost area to agriculture (1081.5 hectares), plantation/orchards (108 hectares), residential (77 hectares), others (49 hectares) and water body (35 hectares).

Box 2. Causes and consequences of transformation of water bodies and marshy areas in srinagar.

\begin{tabular}{|c|c|c|c|}
\hline $\begin{array}{c}\text { Nature and location of Transfor- } \\
\text { mation }\end{array}$ & $\begin{array}{c}\text { Area transformed } \\
(1971-2008)\end{array}$ & Main activities & Impacts \\
\hline $\begin{array}{l}\text { Water body to Agriculture: } \\
\text { 1. } \quad \text { West of Dal Lake: adjoining } \\
\text { Hazratbal ( } 25 \text { hectares) } \\
\text { 2. } \quad \text { Rainawari (40 hectares) } \\
\text { 3. } \quad \text { Lokut Dal (83 hectares) }\end{array}$ & 148 hectares & $\begin{array}{l}\text { Illegal encroachments of the lake area } \\
\text { and practicing of agricultural activi- } \\
\text { ties especially, floating gardens pro- } \\
\text { ducing mainly vegetables. }\end{array}$ & $\begin{array}{l}\text { Shrinking of the Lake, sedi- } \\
\text { mentation and pollution. }\end{array}$ \\
\hline $\begin{array}{l}\quad \text { Water body to Marshy: } \\
\text { 1. East of Dal Lake (58 hectares) } \\
\text { 2. Gagribal (17 hectares) } \\
\text { 3. Lokut Dal adjacent to Gagribal } \\
\text { (10 hectares) } \\
\text { 4. Brari nambal (7 hectares) }\end{array}$ & 92 hectares & $\begin{array}{l}\text { Effluents from houses, hotels, restau- } \\
\text { rants and especially the house boats } \\
\text { lead to over growth of dense weed. }\end{array}$ & $\begin{array}{l}\text { Conversion of Water body to } \\
\text { Marsh. }\end{array}$ \\
\hline $\begin{array}{l}\text { Water body to plantation: } \\
\text { 1. West of Nigeen lake }\end{array}$ & 7 hectares & Tourist related activities & $\begin{array}{l}\text { Shrinking along the western } \\
\text { side of the lake }\end{array}$ \\
\hline $\begin{array}{l}\text { Marshy to Agriculture: } \\
\text { 1. Both in Lokut and Bud Dal basins } \\
\text { in West of Dal Lake (621 hec- } \\
\text { tares) } \\
\text { 2. Dal Lake adjoining to Jogi lankar } \\
\text { (15 hectares) and Rainawari (12 } \\
\text { hectares) } \\
\text { 3. Rakh-i-Gandakshah- Bemina (198 } \\
\text { hectares) } \\
\text { 4. Khumani Chowk ( } 243.5 \text { hectares) }\end{array}$ & 1081.5 hectares & $\begin{array}{l}\text { Marshy lands are filled to convert into } \\
\text { floating gardens to produce crops and } \\
\text { vegetables. }\end{array}$ & $\begin{array}{l}\text { Complete conversion of } \\
\text { Marshy areas to Agriculture, } \\
\text { leading to water logging and } \\
\text { flooding. }\end{array}$ \\
\hline $\begin{array}{l}\text { Marshy to Plantation/Orchard: } \\
\text { 1. Southern Khuhalsar (33.5 hec- } \\
\text { tares) } \\
\text { 2. In Rakh-i-Gandakshah (34 hec- } \\
\text { tares) } \\
\text { 3. Lokut Dal (24.5 hectares) } \\
\text { Brari nambal (16 hectares) }\end{array}$ & 108 hectares & Urban forestry & $\begin{array}{l}\text { Significant area under marsh } \\
\text { got shrunk leading to water } \\
\text { logging and flooding. }\end{array}$ \\
\hline $\begin{array}{l}\text { Marshy to others: } \\
\text { 1. Rakh-i-Gandakshah ( } 29 \text { hectares) } \\
\text { 2. Some patches in the west of Dal } \\
\text { lake at Hazratbal ( } 20 \text { hectares) }\end{array}$ & 49 hectares & Conversion into built-up land & $\begin{array}{l}\text { Complete transformation of } \\
\text { marshy area leading to ex- } \\
\text { tinction of this marsh }\end{array}$ \\
\hline
\end{tabular}




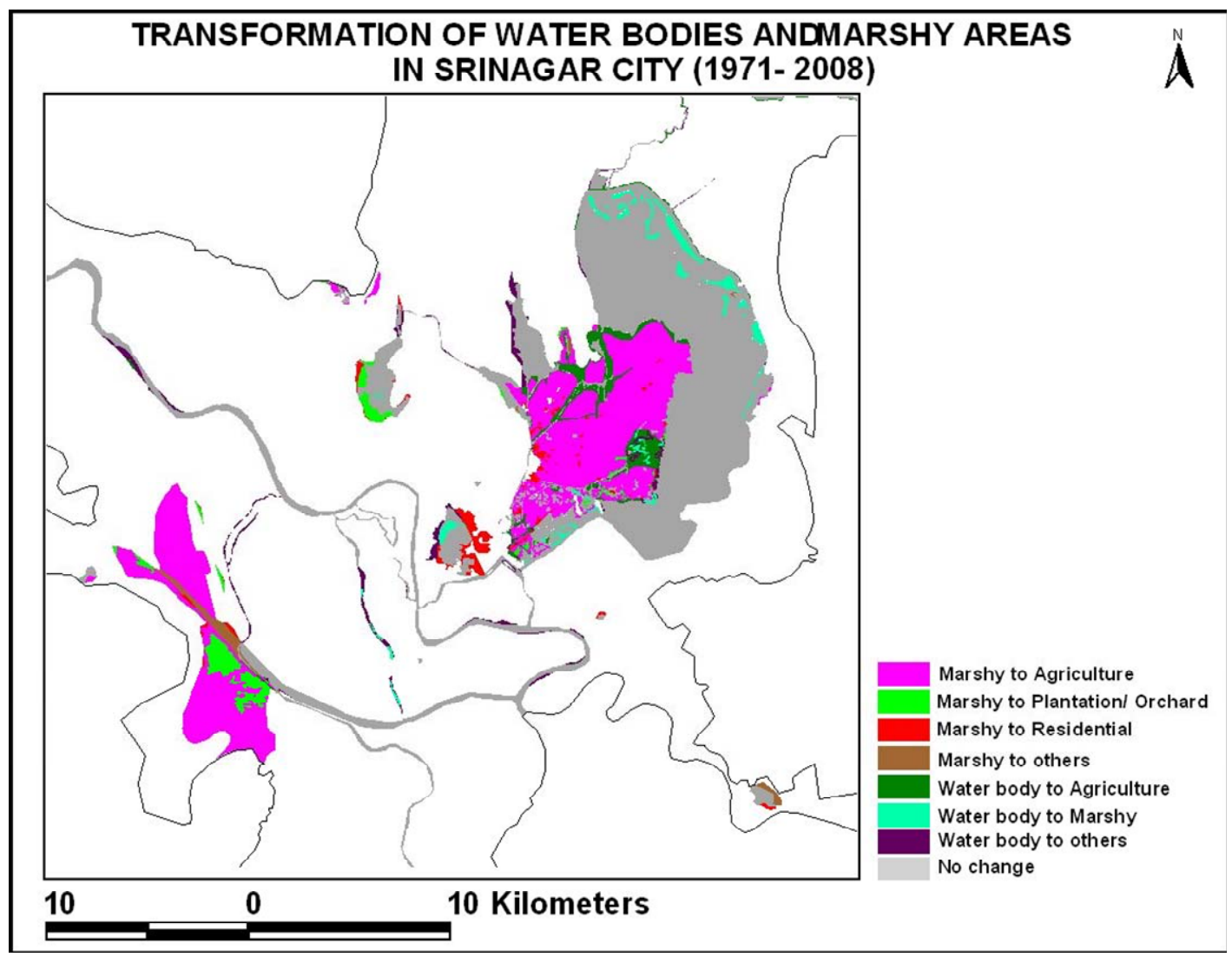

Figure 6. Location of water badies and marshy areas in srinagay city (1971-2008).

However, it gained land from water body (92 hectares) and agriculture (60 hectares).

Water body to Agriculture: During the study period 148 hectares of area under water was transformed to agriculture. The significant transformation of water bodies to agriculture has been observed in the west of the Dal Lake, the area adjoining to the Hazratbal (25 hectares), Rainawari (40 hectares) and in the southern part or Lokut Dal area of Dal Lake (83 hectares). Here the Dal dwellers (Hanjis) have illegally encroached upon the lake area and practicing various agricultural activities especially, floating gardens producing mainly vegetables. This vegetable cultivation is to cater the city demand, which is also crucial to city economy as an estimated vegetable worth 35 crores are produced and supplied from these floating gardens every year.

Water body to Marshy: The Srinagar city has observed 92 hectares of area under water was transformed to marshy lands. This transformation was mainly along the eastern part of Dal Lake (58 hectares), some scattered patches in Gagribal basin (17), adjoining Lokut Dal basin (10 hectares), where rapid undergrowth of weeds, especially the recent grown up weed Azolla Pinnata has converted the water into dense marsh. This growth of weeds was mainly because of various nitrogen and phosphorous effluent discharge from houses, hotels, restaurants and the house boats. Also this type of conversion has been experienced in the Brari Nambal water body (7 hectares) where people have illegally converted water into floating gardens.

Water body to Plantation/Orchard: This transformation has been observed on the east and the west banks of the Nigeen Lake where 7 hectares of water area has been converted into plantation.

Marshy to Agriculture: The Srinagar city has witnessed large scale land transformation of shallow marshy area. The Srinagar city has lost 1081 hectares of marshy area to agricultural lands. This transformation was prominent at Bud and Lokut Dal region of western Dal Lake (621 hectares), some patches in Nigeen Lake, and Dal waters adjacent to Jogi lankar (15 hectares) and Rainawari (12 hectares) etc. Here marshy area was converted into the Floating/vegetable gardens (Rad) by the boat man people (Hanjis) of the lake which is the major source of their income. Similarly, Rakh-i- Gandakshah marsh at Bemina (198 hectares) and Khumani Chowk (243.5hectares) in the west of Srinagar got completely converted into agricultural land because this is a leveled 
plain with good road accessibility.

Marshy to Plantation/Orchard: The Srinagar city has recorded 108 hectares of marshy land transformed plantation/ orchard class. This was mainly in the south of Khushalsar Lake in the north (33.5 hectares), south of Rakh-i- Gandakshah (34 hectares). Some patches have also been transformed in Lokut Dal area of south Dal Lake (24.5 hectares) and 16 hectares in Brari Nambal.

Marshy to others: Marshy land got also transformed to other class i.e., Educational, Governmental, Hospital and Religious class mostly, in the west of the study area at Bemina (29 hectares) and in the west Dal Lake (20 hectares).

\subsection{Urban Land Transformation and Its Impact on Water Bodies of Srinagar City}

The water bodies of Srinagar city are important landscapes of the city because they are not only tourist attractions but are embedded with city's economic, social and cultural existence. These water bodies are also crucial for ecological balance of the city. The present study reveals that the expansion of Srinagar city and land transformation therein has severely affected the aerial extent of water bodies as well as the quality of water. The noticeable impacts and their consequences are as follows:

Settlements around water bodies: The water bodies of Srinagar city is experiencing mushrooming of settlements around the water bodies. The prime victim of this trend is Dal lake which is being occupied by people for residence and over the years it has expanded as well as became denser. At present Dal lake provides shelter to about 50 hamlets with a population of over 50000 people, who have property rights over 300 hectares (6 000 kanals) of agricultural land and 670 hectares (13 400 kanals) of water area. Besides this, a large number of commercial and residential buildings such as hotels, guest houses and restaurants have sprung up in and around the Dal lake. These settlements spill all their wastes into the lakes. This results in increasing levels of pollution because of the ingress of untreated sewage and solid waste from the peripheral areas and from the hamlets into the lake resulting in sedimentation and excessive weed growth. Moreover, reduction and clogging of water channels within the lake because of encroachments leads to reduction of fresh water inflow into the lake.

House boats in water bodies: House boats are one of the most preferred attractions of Srinagar city, presently there are more than 1200 house boats inside the Dal Lake. These house boats also eject out their wastes directly into lake again resulting in sedimentation and excessive weed growth. Presently the 1200 house boats inside the Dal Lake and an estimated 9000 metric tons of waste annually disposed directly into Dal Lake.

Agricultural activity in and around water bodies: The hanjis (Dal dwellers) belong to poor socio-economic class of the city and they draw their livelihood from agricultural activities. These hanjis have illegally encroached upon the lake area by filling up the lake and transforming the lake in to floating gardens. These floating gardens are engaged for vegetable cultivation. This transformation leads not only to shrinking of lake area but agricultural activity also results in increased sedimentation of soil and chemicals in to the lake.

Rise in the influx of nutrients: The water bodies are also subject to pollution with influx of chemicals in them. Studies reveals that there are 15 major drains get emptied into the lake waters which are charged with nutrients and carry about 18.17 tons of phosphorous and 25 tons of inorganic nitrogen, enriching the lake waters and the sediments [18]. Even the water quality of river Jhelum has also got deteriorated due to the direct discharge of urban waste including both domestic and human excreta and almost every water body has now turned into the "Reservoir of Sewage" wastes and effluents [19]. The water tests have also found high level of $\mathrm{pH}$ value, total alkalinity, nitrogen and total phosphorous in the waters of Dal lake [20] (Box 3).

Box 3. Chemical effluents in water bodies of srinagar city.

\begin{tabular}{|c|c|c|c|c|c|c|c|c|}
\hline \multirow{2}{*}{ Parameters } & \multicolumn{2}{|c|}{ Hazratbal Basin } & \multicolumn{2}{|c|}{ Lokut Dal Basin } & \multicolumn{2}{|c|}{ Gagribal Basin } & \multicolumn{2}{|c|}{ Nigeen Basin } \\
\hline & 1977 & 2007 & 1977 & 2007 & 1977 & 2007 & 1977 & 2007 \\
\hline $\mathbf{p H}$ & 7.7-9.5 & 6.9-9.5 & 7.4-9.5 & 7.9-9.2 & 7.5-9.5 & 7.3-9.4 & 7.7-9.5 & $7.2-9.0$ \\
\hline $\begin{array}{l}\text { Total Alkalinity } \\
\text { (mg 1-1) }\end{array}$ & $70-120$ & $44-164$ & $22-210$ & $29-160$ & $70-125$ & $20-126$ & $80-134$ & $22-204$ \\
\hline $\begin{array}{c}\text { Nitrate- Nitrogen } \\
\text { ( } \mu \mathrm{g} 1-1)\end{array}$ & $80-650$ & $\begin{array}{l}100- \\
3680\end{array}$ & $95-691$ & $\begin{array}{l}150- \\
2800\end{array}$ & $80-603$ & $80-3360$ & $90-632$ & $\begin{array}{c}90- \\
3700\end{array}$ \\
\hline $\begin{array}{c}\text { Total Phosphorous } \\
\text { ( } \mu \mathrm{g} 1-1)\end{array}$ & $62-623$ & $76-820$ & $65-620$ & $48-750$ & $70-506$ & $100-840$ & $90-873$ & $96-580$ \\
\hline
\end{tabular}


Growth of weeds in water bodies: The land transformations and activities in and around the water bodies have resulted in rapid undergrowth of weeds in all the water bodies in Srinagar city, especially the recent grown up weed Azolla Pinnata. This has converted the water into dense marsh because of various nitrogen and phosphorous effluents dumped by houses, hotels, restaurants and the house boats, which act as the fertilizer to these weeds. Studies have found that there is an explosive growth of duckweed, water ferns, and algae in the water bodies of Srinagar city [21].

Shrinking of water bodies: This is the most glaring outcome of land transformations in Srinagar city. The present study shows that water bodies/marsh are reduced by nearly 1450 hectares during the study period of 1971 to 2008. Other studies have found this loss even more severe, which suggest that more than 50 percent of the water bodies have been lost in the suburbs of Srinagar city during the last century [22].

Local climatic change: There are also evidences of rise in the mean maximum temperatures of Srinagar city. The main reason attributed to this local microclimatic variation is again large scale land transformation and shrinking water bodies in the city. Studies suggest that mean maximum temperatures during summers shows a rising trend [22]. A perusal of average temperature data in the month of July during the study period have increased by almost 4 degree celsius.

Occurrence of floods and water logging: The shrinking and the squeezing of water bodies and marsh in Srinagar city has also resulted in higher and increased incidence of floods and water logging especially in and after rainy season. The main reason is again the land transformation, since, these marshy areas and water bodies used to act as the sponge and take in water, preventing it to spill in low-lying areas of the city. Now with lesser area under water bodies and marsh, the flood hazard is a regular feature.

\section{Conclusions}

The above analysis clearly points towards the fact that urban expansion has swallowed a significant proportion of the water bodies and the marshy areas of Srinagar city during the study period of 37 years (1971 - 2008) and the process is still continuing. Moreover, the quality of water is also deteriorating at an alarming rate. There is an urgent need to protect and preserve, once the "Paradise on Earth" for future generations. These water bodies are precious because they are not only tourist attractions but they also act as lifeline to the city as it provides livelihood to a large population, directly or indirectly. Thus, proper management is the need of the hour for both maintaining ecological balance as well as sustainability of Srinagar city.

The study suggests three important measures for the sustainable management of water bodies in Srinagar city:

1) The foremost remedy lies in restricting any increase in the settlements in and around these water bodies and marshy lands. In this perspective, the governments' proactive approach is essential because state high court in 2003 has already banned all kinds of constructional activities within 200 meters from the periphery of Dal Lake.

2) Further, the already settled population in and around the lake area should be relocated and rehabilitated outside the Dal Lake periphery. In this context some efforts have already been made by some agencies (Jammu and Kashmir lakes and Water Ways Authority), where some 1221 families living in 441 houses have been resettled but their total rehabilitation is still pending. Government again requires taking initiative to relocate and rehabilitate the remaining 5029 families left there.

3) Another important task for preserving the water bodies is to get rid from duckweed, water ferns, and algae. There must be sincere efforts to perform deweeding and dredging activities on periodic basis in the affected water bodies to maintain water clean. Further, Srinagar city requires operational sewage treatment plants so that no untreated sewage is disposed off in any of the water bodies. Studies have also suggested using weed as raw material to produces organic manure; this will serve dual purpose of cleaning of water and utilizing the waste.

\section{REFERENCES}

[1] M. G. Wolman and F. G. A. Fournier, "Land Transformation in Agriculture,” John Wiley and Sons, Chi Chester, UK, 1987.

[2] P. Blaikie and H. C. Brookfield, "Land Degradation and Society,” Methuen, London, 1987.

[3] S. Fazal, "Urban Expansion and Loss of Agricultural Land,” A GIS Based Study of Saharanpur City, India. Environment and Urbanization, Vol. 12. No. 2, 2000, pp 133-149. doi:10.1177/095624780001200211

[4] J. E. Cohen, "How Many People Can the Earth Support?” W.W. Norton \& Co., New York, 2004.

[5] O. O. Ifatimehin and M. E. Ufuah, "An Analysis of Urban Expansion and Lost of Vegetation Cover in Lokoja Using GIS Techniques,” Journal of Environmental Studies and Human Development, Vol. 17, No. 1, 2006b, pp. 28-36.

[6] O. O. Ifatimehin and S. D. Musa, “Application of Geoinformatic Technology in Evaluating Urban Agriculture and Urban Poverty in Lokoja," Nigerian Journal of Geography and the Environment, 2008.

[7] S. Q. Zhao, J. Y. Fang, S. L. Miao, B. Gu, S. Tao, C. H. Peng and Z. Y. Tang, "The 7-Decade Degradation of a Large Freshwater Lake in Central Yangtze River,” Environmental Science \& Technology, Vol. 39, No. 2, 2005, 
pp. 431-436. doi:10.1021/es0490875

[8] S. K. Karn and H. Harada, "Surface Water Pollution in Three Urban Territories of Nepal,” India, and Bangladesh. Environ Manage, Vol. 28, No. 4, 2001, pp. 483-496.

[9] B. A. M. Bouman, A. R. Castaneda and S. I. Bhuiyan, "Nitrate and Pesticide Contamination of Groundwater under Rice-Based Cropping Systems: Past and Current Evidence from the Philippines,” Agriculture, Ecosystems \& Environment, Vol. 92, No. 2, 2002, pp. 185-199. doi:10.1016/S0167-8809(01)00297-3

[10] J. G. Liu and J. Diamond, "China’s Environment in a Globalizing World,” Nature, Vol. 435, No. 7046, 2005, pp. 1179-1186. doi:10.1038/4351179a

[11] UN Environment Programme, "Global Environment Outlook 2000,” Earthscan, London, 1999.

[12] D. Dudgeon, "Endangered Ecosystems - a Review of the Conservation Status of Tropical Asian Rivers," Hydrobiology, Vol. 248, 1992, pp. 167-191

[13] S. Earle, "The Preservation of Asian Wetlands-Birds and Their Problems," Interdisciplinary Science Reviews, Vol. 19, 1994, pp. 149-165.

[14] J. R. Jensen and D. C. Cowen, "Remote Sensing of Urban/Suburban Infrastructure and Socioeconomic Attributes,” Photogrammetric Engineering and Remote Sensing, Vol. 65, No. 5, 1999, pp. 611-622.

[15] M. Herold, D. Roberts, M. Gardner and P. Dennison, "Spectrometry for Urban Area Remote Sensing - Development and Analysis of a Spectral Library from 350 to 2
400 nm,” Remote Sensing of Environment, Vol. 91, No. 3-4, 2004, pp. 304-319. doi:10.1016/j.rse.2004.02.013

[16] M. Herold, H. Couclelis and K. C. Clarke, "The Role of Spatial Metrics in the Analysis and Modeling of Land Use Change," Computers, Environment and Urban Systems, Vol. 29, No. 4, 2005, pp. 369-399. doi:10.1016/j.compenvurbsys.2003.12.001

[17] LAWDA, "Jammu and Kashmir Lakes and Water Ways Authority: Technical Reports on Dal Lake, Srinagar," 1998, 1999, 2000.

[18] G. M. Rather, M. S. Bhat and T. A. Kanth, "Impact of Urban Waste of Srinagar City on the Quality of Water of River Jehlum,” International Journal of Lakes and Rivers, Vol. 3, No. 1, 2010, pp. 17-24.

[19] R. Gangwar, "Education and Participation Help Conserve the Dal Lake,” Article in Ideas and Experiences for Education for Sustainable Development, Environmental Information System, India, 2008.

[20] H. Rashid and G. Naseem, "Quantification of Loss in Spatial Extent and Wetlands in the Suburbs of Srinagar City during Last Century Using Geospatial Approach,” In: M. Sengupta and R. Dalwani, Eds., Proceedings of Taal2007: The 12th World Lake Conference, 2008, pp, 653- 658.

[21] G. Singh, et al., "Climate Change Impact and Awareness. Peoples Empowerment Mission,” Srinagar and UNESCO, New Delhi, 2000. 